\title{
Seasonal Ground Solar Thermal Energy Storage - Review of Systems and Applications
}

\author{
Pavlov, Georgi Krasimiroy; Olesen, Bjarne W.
}

Published in:

Proceedings

Publication date:

2011

Document Version

Early version, also known as pre-print

Link back to DTU Orbit

Citation (APA):

Pavlov, G. K., \& Olesen, B. W. (2011). Seasonal Ground Solar Thermal Energy Storage - Review of Systems and Applications. In Proceedings (pp. P-1.2-07)

\section{General rights}

Copyright and moral rights for the publications made accessible in the public portal are retained by the authors and/or other copyright owners and it is a condition of accessing publications that users recognise and abide by the legal requirements associated with these rights.

- Users may download and print one copy of any publication from the public portal for the purpose of private study or research.

- You may not further distribute the material or use it for any profit-making activity or commercial gain

- You may freely distribute the URL identifying the publication in the public portal

If you believe that this document breaches copyright please contact us providing details, and we will remove access to the work immediately and investigate your claim. 


\title{
SEASONAL GROUND SOLAR THERMAL ENERGY STORAGE - REVIEW OF SYSTEMS AND APPLICATIONS
}

\author{
Georgi K. Pavlov ${ }^{1}$, Bjarne W. Olesen ${ }^{1}$ \\ ${ }^{1}$ International Centre for Indoor Environment and Energy - ICIEE \\ Department of Civil Engineering/Technical University of Denmark, Kgs. Lyngby (Denmark)
}

\section{Introduction}

The building sector accounts for about $40 \%$ of the total energy use in the European Union (EU) countries (International Energy Agency, IEA 2009). However, at the same time the building sector has a documented cost-effective saving potential of up to $80 \%$, which can be effected over the next 40 years. In order to ensure these considerable energy conservations and at the same time to apply renewable energy in an optimal way, the development of integrated, intelligent technologies for buildings is needed.

Energy demands in buildings vary on daily, weekly and seasonal basis. These demands can be matched with the help of Thermal Energy Storage (TES) systems that operate synergistically and are carefully matched to each specific application. TES systems have the potential of making the use of thermal equipment more effective, and are important means of offsetting the mismatch between thermal energy availability and demand. Well designed systems can reduce initial and maintenance costs and improve energy efficiency (Dincer et al. 1996, 1997).

A variety of TES techniques for heating and cooling applications have been developed over the past decades. Increasing energy demands, shortages of fossil fuels and environmental concerns are increasing the interest in the development of economically competitive and reliable means of seasonal storage of thermal energy. Different examples about the efficient utilization of natural and renewable energy sources, cost savings and increased efficiency achievable through the use of seasonal TES can be considered (Dincer \& Rosen 2011, Nordell 2000).

The interest in large-scale seasonal solar thermal energy storage started with the oil crisis in the early seventies. The objectives of such systems are to store solar heat collected in summer for space heating in winter. These systems contribute significantly to improving the energy efficiency and reducing the greenhouse gas emissions to the atmosphere.

The main issue impeding solar thermal technologies from achieving their full potential for space heating and domestic hot water (DHW) applications is related to the fact that the energy source has intermittent nature and its effective utilization is dependent on the availability of efficient and effective energy storage systems. This is particularly true at high latitude locations, where seasonal variations of solar radiation are significant, and in cold climates, where seasonally varying space heating loads dominate energy consumption.

This literature review paper attempts to summarize developments during the last four decades in seasonal solar thermal energy storage in the ground, using different storage concepts. The aim is to provide the basis for development of new intelligent seasonal TES possibilities for use in combination with space heating and domestic hot water applications.

\section{Underground thermal energy storage concepts}

The principle methods available for seasonal storage of solar thermal energy mostly store energy in the form of sensible heat. Storage of sensible heat results in energy losses during the storage time. These losses are function of storage time, storage temperature, storage volume, storage geometry, and thermal properties of the storage medium. Since seasonal solar thermal energy storage requires large inexpensive storage volumes, due to the large storage timescales, the most promising technologies were found in the ground. Such systems are called underground thermal energy storage (UTES) systems (Nordell 2000). Among the UTES systems developed since 1970s, the ongoing engineering research focused mainly on four types of storages: water tank, watergravel pit, aquifer thermal energy storage (ATES), borehole thermal energy storage (BTES), Figure 1.

Water tank thermal energy storage usually consists of a reinforced concrete tank partially or fully buried in the ground, which can be built nearly independently of geological conditions. It is thermally insulated at least in the 
roof area and on the vertical walls. Furthermore, steel liners are introduced in the structure to guarantee water tightness and to reduce heat losses caused by vapor transport through the walls (Schmidt et al. 2004). Due to high specific heat of water, and the possibility for high capacity rates for charging and discharging, this technology seems to be the most favorable from a thermodynamic point of view.

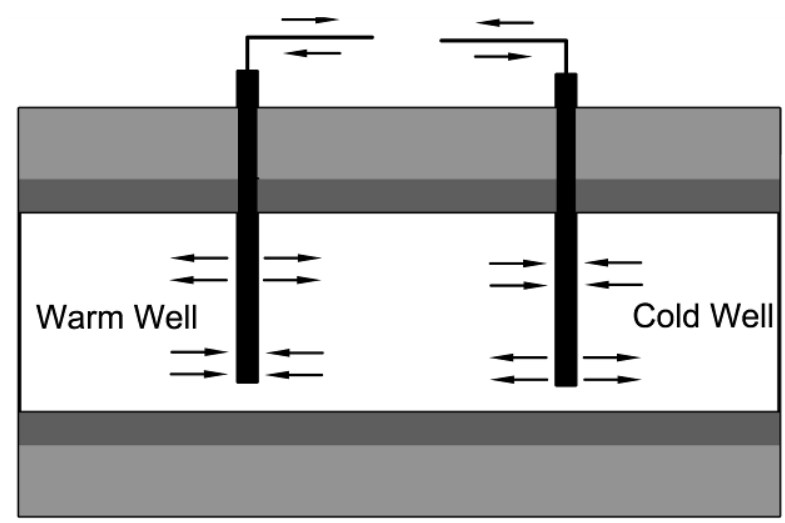

Aquifer Thermal Energy Storage

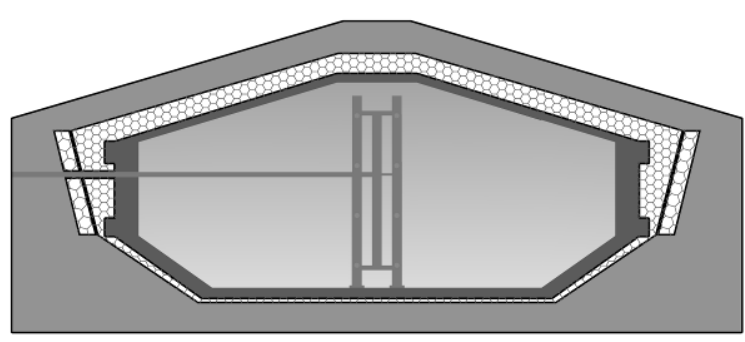

Water Tank Storage

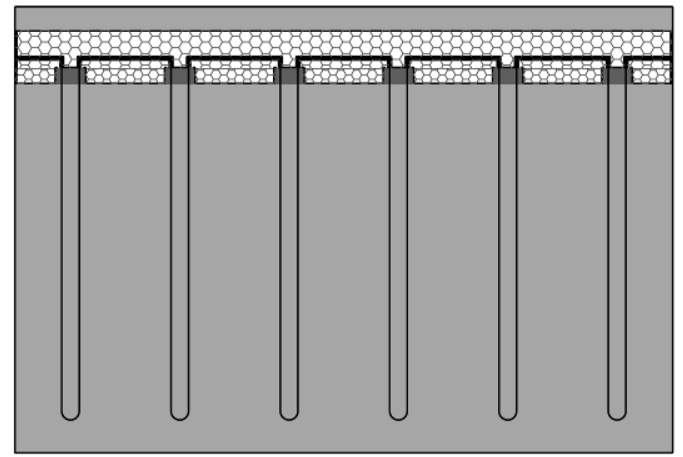

Borehole Thermal Energy Storage

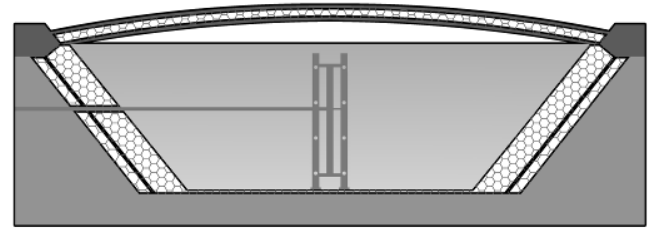

Water-Gravel Pit Storage

Fig. 1: Underground thermal energy storage concepts

Gravel-water pits are normally buried in the ground and need to be waterproofed and insulated at least at the side walls and on the top (Schmidt et al. 2004). Heat is charged into and discharged out of the store either by direct water exchange or by plastic piping installed in different layers inside the store. The gravel-water mixture has lower specific heat capacity than water alone and for this reason the volume of the whole basin has to be higher compared to hot water tank heat storage to obtain the same heat storage capacity.

Tab. 1: Comparison of storage concepts (Schmidt et al. 2003, Novo et al. 2010)

\begin{tabular}{|c|c|c|c|c|}
\hline Storage concept & Water tank & Gravel-water pit & Aquifer & Borehole \\
\hline Storage medium & water & gravel-water & sand/water-gravel & soil/rock \\
\hline $\begin{array}{l}\text { Heat capacity, } \\
\mathrm{kWh} / \mathrm{m}^{3}\end{array}$ & $60-80$ & $30-50$ & $30-40$ & $15-30$ \\
\hline $\begin{array}{l}\text { Storage volume for } 1 \\
\mathrm{~m}^{3} \text { water equivalent }\end{array}$ & $1 \mathrm{~m}^{3}$ & $1.3-2 \mathrm{~m}^{3}$ & $2-3 m^{3}$ & $3-5 m^{3}$ \\
\hline $\begin{array}{l}\text { Geological } \\
\text { requirements }\end{array}$ & $\begin{array}{l}\text { - Stable ground } \\
\text { conditions } \\
\text { - Preferably no } \\
\text { ground water } \\
\text { - 5-15 m deep }\end{array}$ & $\begin{array}{l}\text { - Stable ground } \\
\text { conditions } \\
\text { - Preferably no } \\
\text { ground water } \\
\text { - 5-15 m deep }\end{array}$ & $\begin{array}{l}\text { - Natural aquifer layer, } \\
\text { high hydraulic } \\
\text { conductivity } \\
\text { - Confining layers on } \\
\text { top and below } \\
\text { - No or low natural } \\
\text { ground water flow } \\
\text { - Suitable water } \\
\text { chemistry at high } \\
\text { temperatures }\end{array}$ & $\begin{array}{l}\text { - Drillable ground } \\
\text { - High heat capacity } \\
\text { - High thermal } \\
\text { conductivity } \\
\text { - Low hydraulic } \\
\text { conductivity } \\
\text { - Natural ground water } \\
\text { flow less than } 1 \mathrm{~m} / \mathrm{a} \\
\text { - 30-200 m deep }\end{array}$ \\
\hline
\end{tabular}

Aquifers are below-ground widely distributed sand, gravel, sandstone or limestone layers with high hydraulic conductivity which are filled with groundwater (Schmidt et al. 2004). If there are impervious layers above and below and no or low natural groundwater flow, they can be used for heat storage. In this case, two wells or groups of wells are drilled into the aquifer and serve for extraction or injection of groundwater. During charging periods cold groundwater is extracted from the cold well, heated up by the solar system and injected into the hot 
well. In discharging-periods the flow direction is reversed. Especially for high temperature heat storage a good knowledge of the mineralogy, geochemistry and microbiology in the underground is necessary to prevent damage to the system caused by well-clogging, scaling etc.

In borehole thermal energy storage the heat is directly stored in the ground. Suitable geological formations are e.g. rock or water-saturated soils (Schmidt et al. 2004). U-pipes, so called ground heat exchangers, are inserted into vertical boreholes, into a depth of 30-200 m, to build a huge heat exchanger. The boreholes are usually filled with groundwater (Northern Europe), or with bentonite, quartz sand or thermally enhanced grouts (North America, Central Europe). While water is running in the U-pipes heat can be fed in or out of the ground. The heated ground volume comprises the volume of the storage. At the top of the store usually there is a heat insulation layer to reduce heat losses to the surface. One advantage of this type of storage is the possibility for a modular design. Additional boreholes can be connected easily and the store can grow with e.g. the size of a housing district. The size of the store has to be three to five times higher than that of a hot water heat store to obtain the same heat capacity. Because of the lower capacity at charging and discharging usually a buffer store (water tanks) is integrated into the system. Table 1 summarizes some of the characteristics of the main seasonal storage concepts.

\section{Seasonal storage of solar thermal energy for heating applications}

Seasonal storage of solar thermal energy for space heating purposes has been under investigation in Europe since the mid 1970s within large-scale solar heating projects. Most large-scale solar systems have been built in Sweden, Denmark, The Netherlands, Germany and Austria (Dalenbäck 2007). The first demonstration plants were developed in Sweden in 1978/1979, based on results from a national research programme (Dalenbäck et al. 1985). The seasonal storage concept research work continued within the IEA "Solar Heating and Cooling" programme. Experiences have been gained and exchanged in Task VII "Central Solar Heating Plants with Seasonal Storage (CSHPSS)” since 1979 in many countries. In the past decade, the main activities have been within the work initiated in the CSHPSS Working Group, IEA Solar Heating and Cooling Programme as well as the work carried out in Europe within the EU/APAS-project "Large-Scale Solar Heating Systems”, Fisch et al. (1998). Figure 2 shows a scheme of a CSHPSS (distributed rooftop solar collectors, central plant with heat pump, solar collector and heat distribution networks).

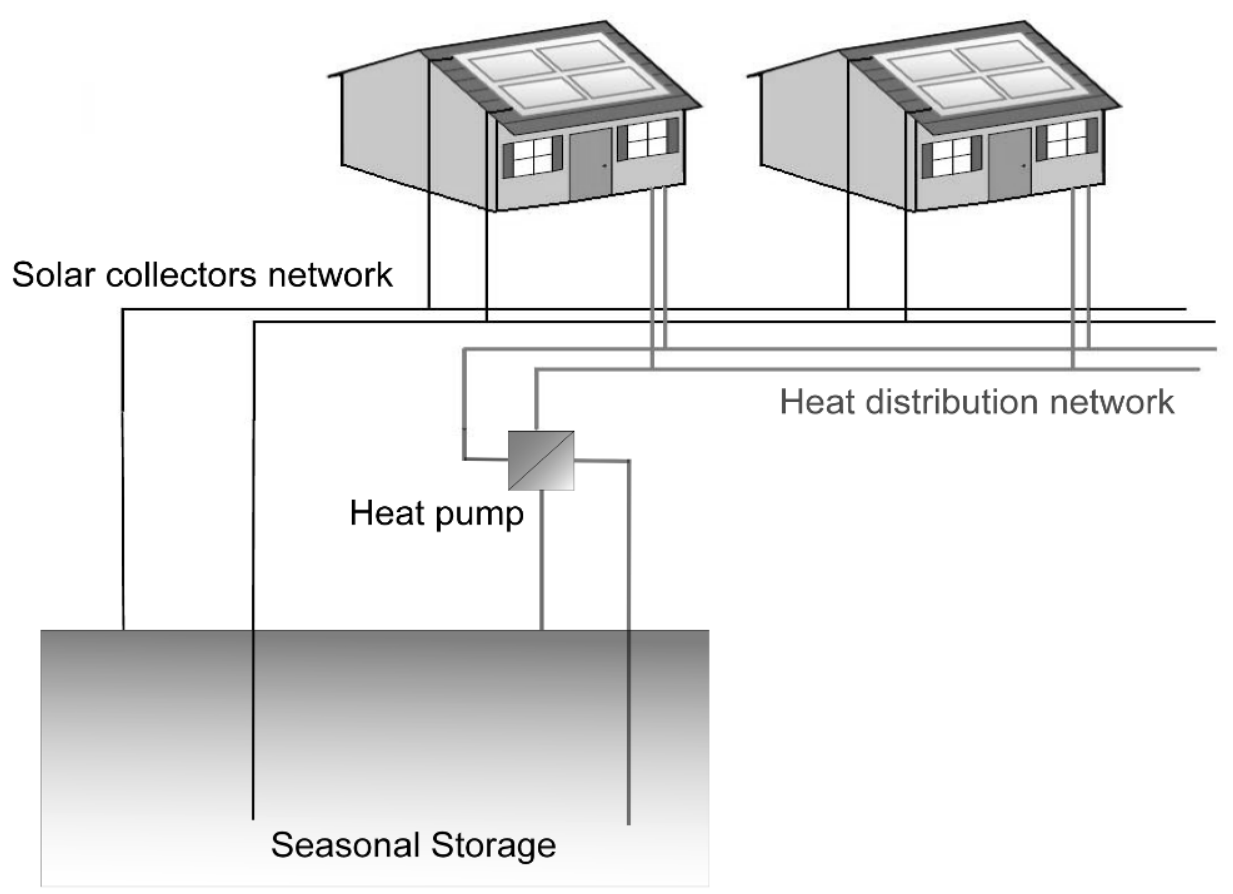

Fig. 2: Scheme of a Central Solar Heating Plant with Seasonal Storage

So far, the development of seasonal storage has been aimed at heating large district system stores in order to fulfill technical viability and cost effectiveness by using large storage volumes. Fisch et al. (1998) reviewed large scale solar plant development in Europe during the 1990s. The work refers to two large-scale solar heating applications: systems with short-term (diurnal) storage designed to supply $10-20 \%$ of the annual heating 
demand or $50 \%$ of the domestic hot water; and systems with long-term (seasonal) storage capable of supplying $50-70 \%$ of the annual heating demand. Within the findings of that work was that large-scale solar applications benefit from the effect of scale. Compared to small solar domestic hot water systems, the solar heat cost can be cut at least in third. Among the main results of the evaluation of the existing projects was the need to reduce the cost-benefit ratio for CSHPSS.

The experimental plants built in some European countries involve the development of new concepts of seasonal storage such as duct storage, natural aquifer, and pit storage concepts using high performance concrete and new construction technologies. Lottner et al. (2000) reviewed long-term national monitoring programme Solarthermie-2000 of large-scale solar heating plants, with and without seasonal storage, in Germany. The study reveals that at present the specific storage costs for seasonal storage of solar energy are still too high and many efforts must be made to achieve technical and economic feasibility. Schmidt et al. (2004) reviewed detailed results of the same monitoring program. The technology of central solar heating plants is described and advices about planning and costs, for improving and optimizing the installations in order to make such concepts more economic, are given. In Bauer et al. (2010) monitoring results of CSHPSS of the same program and its continuation Solarthermie-2000plus are reviewed. The different types of thermal energy stores and the affiliated central solar heating plants and district heating systems are described. The design operational characteristics, of the CSHPSS under investigation, are compared with measured operational data.

\subsection{Seasonal storage in water tanks}

Different seasonal water heat storage tanks integrated in central solar heating plants with seasonal storage have been build in Germany since 1995 within the R\&D programmes Solarthermie-2000 and Solarthermie-2000plus (Lottner et al. (2000), Schmidt et al. (2004), Bauer et al. (2010)).

The water tank storage concept was tested in a small pilot heat store of $600 \mathrm{~m}^{3}$ in Rottweil (Kübler et al. 1997). The underground cylindrical tank was built of concrete and additional inner stainless-steel liner to ensure water tightness and to reduce heat losses by steam diffusion. Insulation was applied on the top and the side walls. The aim of the project was to demonstrate the feasibility of the technology and to gain practical experience for the construction of larger stores. During 1995/1997 two full scale CSHPSS of this type were build in Hamburg and Friedrichshafen, with $4500 \mathrm{~m}^{3}$ and $12000 \mathrm{~m}^{3}$ storage volumes respectively. The plants operate with no major technical problems. However, they do not satisfy the cost effectiveness goal due to high construction costs (Kübler et al. 1997).

With the development of a new high-density concrete (HDC) material with lower vapor permeability, in Hannover a hot water heat store without an inner steel liner was built (Schmidt et al. 2004). Another development was achieved by fixing an additional charging and discharging device with a variable height in the middle of the store. With this device, the temperature stratification in the store can be improved and simultaneous charging and discharging is possible.

New demonstration plants for solar-assisted district heating with seasonal thermal energy storage were developed within the R\&D programme Solarthermie-2000plus (Schmidt et al. 2006). Advances were made in stratification devices and heat insulation in the water tank storage projected for a building in Munich. The specific investment cost of this construction is expected to be significantly lower compared to previous projects.

Several demonstration plants with large-scale solar-heated seasonal heat storage were constructed in Sweden in the early 1980s. In 1979, the solar heating plants connected to new residential areas at Ingelstad and Lambohov became operative. In Ingelstadt, the seasonal heat store was a $5000 \mathrm{~m}^{3}$ cylindrical concrete tank constructed on the ground with thermal insulation. The results show low solar collector efficiency and great heat losses. The heat store of the plant in Lambohov was a $10000 \mathrm{~m}^{3}$ excavated rock pit insulated with cement-bound lightweight sintered clay granules and lightweight concrete, and water sealed with butyl rubber (Dalenbäck et al. 1985). The performance revealed good agreement with the predictions except for the higher heat losses caused by wet thermal insulation, which were not taken into account in the predictions.

Attempts to validate CSHPSS technology have been made in Denmark since 1990. A seasonal storage tank using prefabricated concrete elements was tested in Hoerby. The tank had a volume of $500 \mathrm{~m}^{3}$ and was sealed by a dense bentonite-concrete coating. In 1991, a $3000 \mathrm{~m}^{3}$ heat storage tank was build in Herlev. The storage unit of steel sheet piles and concrete cover, was insulated by polyurethane plates sealed by an EPDM rubber membrane. The stores showed leakage problems at the beginning and were not competitive for large storage volumes (Heller 2000). 


\subsection{Seasonal storage in gravel-water pits}

The first large-scale heat storage of solar energy project was developed in the Institute for Thermodynamics and Thermal Engineering of Stuttgart University in 1984 (Hahne 2000). Based on the satisfactory results from the pilot plant, the same construction aspects were applied in the $8000 \mathrm{~m}^{3}$ gravel-water heat storage built in a demonstration plant in Chemnitz (Schmidt et al. 2004). The liner used was high-density polyethylene (HDPE) and the thermal insulation was expanded polystyrene. The heating plant is in operation since 1999.

Another heat store of $1500 \mathrm{~m}^{3}$ is in operation in Steinfurt since in 1998. Some modifications were applied, in comparison with previous projects, related to the liner and thermal insulation materials. The store included an indirect heat exchanger system consisting of polyethylene (PE) tubes (Pfiel et al. 2000). The newest German pit storage is build in Eggenstein in 2009 (Bauer et al. 2010). It is the first pit storage with a self-supporting roof. The system has a $4500 \mathrm{~m}^{3}$ gravel-water thermal energy store. A heat pump is used for discharging the ground store to lower temperatures in order to achieve better storage efficiencies.

Another option of gravel-water storage was developed at the Technical University of Denmark. The first construction was a $540 \mathrm{~m}^{3}$ store sealed with a HDPE liner and covered by a floating cover made of an HDPE liner, expanded polystyrene insulation and a butyl top liner. A few years later, the reservoir was reconstructed to form an artificial aquifer store by means of filling the pit with gravel and by adding direct and indirect heat exchangers; no results were obtained at that time (Heller et al. 2000).

Based on earlier work and experiences from the Technical University of Denmark, the test storage of Ottrupgaard was constructed in 1996. It has a volume of $1500 \mathrm{~m}^{3}$. The storage was tightened with bottom and side liner of $85 \mathrm{~cm}$ clay, placed on the outside on an EPDM-rubber. The experiences from the test store were that the clay/EPDM liner is expensive to construct. Furthermore, it showed to be difficult to make it sufficiently tight and to localize and repair leakages. The floating cover was an expensive construction.

The $10000 \mathrm{~m}^{3}$ storage in Marstal was designed to test a simpler and cheaper construction than the Ottrupgaard storage. The construction summarizes earlier experiences and studies as well as new studies on e.g. liner types. It has a single welded plastic liner on bottom and sides and a simple floating cover. The seasonal storage solar system is part of a district heating network (Energinet.dk Project 2006).

\subsection{Borehole thermal energy storage}

Since 1997, a pilot borehole thermal energy storage is in realization in Neckarsulm, Germany, as part of the Solarthermie-2000 programme. The BTES presently contains a volume of $63360 \mathrm{~m}^{3}$ with 528 borehole heat exchangers in a depth of $30 \mathrm{~m}$. The heat distribution network is supplied either by the buffer tanks or the BTES, depending on the temperature level. A gas condensing boiler is used for additional heat supply if none of the thermal energy stores is able to cover the heat demand at the requested temperature level. Further details of the solar plant can be found in Nußbicker et al. (2003) and Bauer et al. (2010).

The borehole thermal energy storage built in Crailsheim indicates the next generation of this kind of storages. The project description and design prerequisites are given in Mangold (2007). The BTES has a total volume of $37500 \mathrm{~m}^{3}$ with 80 borehole heat exchangers in a depth of $55 \mathrm{~m}$. A buffer storage tank of $480 \mathrm{~m}^{3}$ is added to the system because of the high capacity rates of the solar collectors during summer. Since the high capacity rate cannot be charged directly to the BTES during the day, it is distributed over longer period of time with the help of the buffer storage tank. The heat from the seasonal store is transferred to a diurnal storage tank of $100 \mathrm{~m}^{3}$ either directly or via a heat pump. The heat pump allows higher usability and increases the storage capacity of the seasonal heat store. In addition the temperature level in the BTES is reduced which results in lower storage heat losses. Furthermore the efficiency of the CSHPSS becomes more robust against high return temperatures from the heat distribution network.

Different type of CSHPSS is built in Attenkirchen (Schmidt et al. 2004). The heat store is a combined hot-water and borehole heat store. A central concrete tank with a volume of $500 \mathrm{~m}^{3}$ is surrounded by 90 GHEs (30 m deep). Depending on the temperature levels in the two parts of the store, heat pumps use the GHEs as heat source and deliver heat into the hot-water tank or use the hot-water tank as heat source and supply heat into the district heating network.

A preliminary study of a solar-heated low-temperature space-heating system with seasonal storage in the ground has been performed for a planned residential area with 90 single family houses with 1080 MWh total heat demand in Anneberg, Sweden (Nordell et al. 2000). A BTES in crystalline rock of $60000 \mathrm{~m}^{3}$ (99 borehole heat exchangers, each having a depth of $65 \mathrm{~m}$ ) is used as a seasonal store. The temperature of the seasonal store 
varies between $30^{\circ} \mathrm{C}$ and $45^{\circ} \mathrm{C}$ over the year. The floor heating system is designed for $30^{\circ} \mathrm{C}$ supply water temperature. Electrical heaters are used to produce peak heating. The system performance has been evaluated using the simulation models TRNSYS and MINSUN together with the ground storage module DST (Duct Storage Model) (Claesson et al. 1981, Hellstrom 1989, Mazzarella 1989, Mazzarella 1990, Pahud 1996, Klein 2004). The study implies and economically feasible design for a total annual heat demand of about $2500 \mathrm{MWh}$.

The partly solar heated building area in Anneberg, Sweden, has been built in 2002 (Lundh et al. 2008). The final design is carried out for 50 residential units with an annual heat demand of $550 \mathrm{MWh}$. The heating system is designed for low-temperature heating $\left(32^{\circ} \mathrm{C} / 27^{\circ} \mathrm{C}\right.$ supply/return water temperatures) and individual electric heaters for covering peak demands. The mean temperature of the seasonal store has been $30-45^{\circ} \mathrm{C}$. Evaluation of the system performance has been done during final design stage, using the simulation models TRNSYS, MINSUN and the ground storage module DST. The system performance would result with a solar fraction of $70 \%$ after $3-5$ years of operation, required for initial heating of the store and surrounding ground.

In Canada, the first seasonal solar thermal energy storage was built in 2006 in the residential area in Okotoks as borehole thermal energy storage. The BTES volume of $35000 \mathrm{~m}^{3}$ consists of 144 vertical boreholes, each having a depth of $37 \mathrm{~m}$. Results from computer simulations indicate that the system will reach about $90 \%$ solar fraction for space heating after an initial 5 years charging period (McDowell \& Thornton, 2008). The predicted end of summer BTES temperature is around $80^{\circ} \mathrm{C}$. Such a high storage temperature has two drawbacks. First, the return temperature to the solar collectors is relatively high which leads to relatively low solar collector efficiencies. Second, heat losses from the borehole storage are relatively high as they represent $60 \%$ of the injected heat (Sibbitt et al., 2007).

Chapuis and Bernier (2009) proposed a new seasonal storage strategy based on the concept of the system at Okotoks. The storage temperature is kept relatively low in order to limit heat losses and improve solar collector efficiencies. The temperature level is raised using heat pumps to supply heat at an acceptable temperature for space heating. The proposed configuration is simulated with TRNSYS using the DST model. Results from simulations indicate that it is possible to keep the seasonal storage temperature at an annual average slightly above the annual mean ambient temperature using a relatively small solar collector area leading to relatively high solar collector efficiencies. Combined with a heat pump, it is shown that this system can reach a solar fraction of $78 \%$.

\subsection{Aquifer thermal energy storage}

In the solar assisted district heating plant of the pilot project in Rostock (Germany) an aquifer is used as a low temperature seasonal storage. Due to the small size of the plant, the shallow $30 \mathrm{~m}$ (98.5 ft) deep aquifer has to be operated in a temperature range between $10^{\circ} \mathrm{C}$ and $50^{\circ} \mathrm{C}$. A maximal fraction of the stored solar heat can be recovered by a heat pump. In 2003 this pilot plant was the first of all plants that reached the strategic solar fraction of $50 \%$ of the yearly heat demand. Further details of the CSHPSS in Rostock can be found in Lottner et al. (2000), Schmidt et al. (2000), Schmidt et al. (2004) and Bauer et al. (2010).

\section{Experiences from pilot projects and demonstration plants}

Seasonal heat storage needs large volumes of storage to supply the energy stored during summertime along winter. Those large stores require the development of technologies capable of minimizing heat losses in order to preserve the thermal performance and life time of the solar heating plant. These approaches must be coupled with low investment, at least lower than conventional heating systems.

The seasonal energy storage technologies for solar energy applications are characterized by many factors such as solar collectors, annual sun exposure, heat distribution networks, heat demand and insulation of the buildings, and the seasonal storage. Once these technologies have been well developed, the main effort consists in reducing costs in order to make them market competitive against conventional energy sources. To determine the economy of a storage, the investment and maintenance costs of the storage have to be related to its thermal performance (the cost of the usable stored energy).

Table 2 summarizes the technical characteristics of some demonstration plants in central solar heating systems with water tank, gravel-water pit, borehole, and aquifer storage. The experimental projects have been selected as they are large-scale pilot plants. An overview of the effectiveness of diverse configurations of these systems, including solar heat systems costs are provided. The given numbers for solar fraction of total heat delivered are simulated values for long-term operation. Depending on the type of seasonal heat store, the systems have start- 
up times of 3 to 5 years to reach the normal operating conditions. Within this time the underground around the seasonal storage has to be heated up and hence heat losses are higher than in the long-time operation. Because of this, the system efficiency is lower in the first years of plant operation (Schmidt et al. 2004).

A substantial part of the investment cost of CSHPSS is caused by the seasonal heat storage. Four different storage types for seasonal heat storage have been investigated in this article. The selection of a specific storage type depends on the geological and hydrogeological situation in the ground at the respective construction site. A preliminary geological examination of the site is recommended especially for aquifer and borehole thermal energy storage. If different storage types are feasible, an economic optimization via system simulations should be conducted by taking the construction costs of the different concepts into account.

Tab. 2: Technical data of CSHPSS (Novo et al. 2010, Dalenbäck et al. 1985, Lottner et al. 2000, Schmidt et al. 2004, Schmidt et al. 2006, Heller 2000, Wong et al. 2006)

\begin{tabular}{|c|c|c|c|c|c|c|c|}
\hline $\begin{array}{l}\text { CSHPSS with } \\
\text { storage type }\end{array}$ & $\begin{array}{l}\text { Heated living } \\
\text { area }\end{array}$ & $\begin{array}{c}\text { Total heat } \\
\text { demand, } \\
\text { GJ/a }\end{array}$ & $\begin{array}{c}\text { Solar } \\
\text { collector } \\
\text { area, } \mathbf{m}^{2}\end{array}$ & $\begin{array}{c}\text { Storage } \\
\text { volume, m }\end{array}$ & $\begin{array}{c}\text { Solar } \\
\text { fraction, } \\
\%\end{array}$ & $\begin{array}{l}\text { Maximum design } \\
\text { storage } \\
\text { temperature, }{ }^{\circ} \mathrm{C}\end{array}$ & $\begin{array}{c}\text { Solar heat cost at } \\
\text { analysis date, } \\
\text { MWh }^{-1}\end{array}$ \\
\hline \multicolumn{8}{|l|}{ Water tank } \\
\hline Hamburg, DE & $14800 \mathrm{~m}^{2}$ & 5796 & 3000 & 4500 & $49 *$ & 95 & 256 EUR \\
\hline Friedricshafen, DE & $39500 \mathrm{~m}^{2}$ & 14782 & 5600 & 12000 & $47^{*}$ & 95 & 158 EUR \\
\hline Hannover, DE & $7365 \mathrm{~m}^{2}$ & 2498 & 1350 & 2750 & $39 *$ & 95 & 414 EUR \\
\hline Munich, DE & 300 apt. & 8280 & 2900 & 5700 & $47 *$ & 95 & 240 EUR \\
\hline Ingelstad, SE & 52 houses & & 1320 & 5000 & 14 & & 1900 SEK \\
\hline Lambohov, SE & 55 houses & & 2700 & 10000 & 37 & & 1100 SEK \\
\hline Hoerby, DK & & & & 500 & & & \\
\hline Herlev, DK & & 4520 & 1025 & 3000 & 35 & & \\
\hline \multicolumn{8}{|l|}{ Gravel-water pit } \\
\hline Stuttgart, DE & & 360 & 211 & 1050 & 60 & 85 & \\
\hline Chemnitz, DE & $4680 \mathrm{~m}^{2}$ & 4320 & 2000 & 8000 & $42 *$ & 85 & 240 EUR \\
\hline Steinfurt, DE & $3800 \mathrm{~m}^{2}$ & 1170 & 510 & 1500 & $34 *$ & 90 & 424 EUR \\
\hline Eggenstein, DE & $12000 \mathrm{~m}^{2}$ & 3276 & 1600 & 4500 & $40 *$ & 80 & \\
\hline Ottrupgaard, DK & & 1630 & 560 & 1500 & 16 & & \\
\hline \multicolumn{8}{|l|}{ BTES } \\
\hline Neckarsulm, DE & $20000 \mathrm{~m}^{2}$ & 1663 & 5000 & 63400 & $50 *$ & 85 & 172 EUR \\
\hline Crailsheim, DE & $\begin{array}{l}260 \text { houses, } \\
\text { school and } \\
\text { gymnasium }\end{array}$ & 14760 & 7300 & 37500 & $50 *$ & 85 & 190 EUR \\
\hline Attenkirchen, DE & $6200 \mathrm{~m}^{2}$ & 1753 & 800 & 10000 & $55^{*}$ & 85 & 170 EUR \\
\hline Anneberg, SE & $9000 \mathrm{~m}^{2}$ & 3888 & 3000 & 60000 & $60 *$ & 45 & 1000 SEK \\
\hline Okotoks, CA & 52 houses & 1900 & 2293 & 35000 & $90 *$ & 80 & \\
\hline \multicolumn{8}{|l|}{ ATES } \\
\hline Rostock, DE & $7000 \mathrm{~m}^{2}$ & 1789 & 1000 & 20000 & $62 *$ & 50 & 255 EUR \\
\hline
\end{tabular}

Water tank thermal energy storages are technically feasible and work well. However, construction costs and thermal losses are still too high. Experiences from the plants build in Hamburg and Friedrichshafen have shown that the main cost for hot-water storage tanks is caused by the concrete construction, ground works, insulation, and the use of steel liners to reduce water permeability (Kübler et al. 1997). Considerable cost reductions can be obtained with the development of high-density concrete materials, which would allow the omission of the use of expensive steel liners for the storage construction (Schmidt et al. 2004). The water tank storage in Hannover is the first one utilizing that concept in a large scale. Another novelty in that project has been the introduction of stratification devices in the water tank store. Problems with high thermal losses due to wet thermal insulation have been experienced in Sweden in the past (Dalenbäck et al. 1985), and have revealed the importance of water tank insulation for the long-term performance of CSHPSS. Advances in stratification devices and heat insulation have resulted in significantly lower construction costs for the seasonal storage in Munich, than cost experienced in previous projects (Schmidt et al. 2006). Further research and development related to high- 
density concrete materials, prefabricated sandwich elements for water tank walls construction, and simultaneous charging and discharging stratification devices, would give the possibility of improving the thermal performance and decreasing the construction costs for water tank seasonal storage technology.

Experiences with the gravel-water storage in Chemnitz have shown that sealing of the pit, insulation and ground works account for significant part of the costs (Schmidt et al. 2004). The seasonal storages in Steinfurt (Pfiel et al. 2000) and Ottrupgaard (Heller 2000) have shown that the construction of the wall (liner, insulation) can barely be realized at the required low costs to be cost-effective for seasonal storage. Moisture protection of the insulation is also important for the concept. In addition, the seasonal gravel-water pit storage in Ottrupgaard has shown difficulties to make it sufficiently tight and to localize and repair leakages. The concept of floating cover has been investigated for the plants in Ottrupgaard and Eggenstein (Bauer et al. 2010), appearing to be an expensive construction. Further research for developing cost effective solutions is needed. Related to the thermal performance of the concept, further developments in direct and indirect heat exchangers are needed.

For BTES, the experiences with CSHPSS built in Neckarsulm (Nußbicker et al. 2003, Bauer et al. 2010), Crailsheim (Mangold 2007) and Anneberg (Nordell et al. 2000, Lundh et al. 2008) show that the major investment for the solar plant is the cost of building the storage; e.g. drilling of boreholes, construction of heat exchangers, refill of boreholes. As drilling costs increase with the depth of the borehole, the length and the number of ducts are important. Thermal properties (heat capacity, thermal conductivity) of the ground determine the spacing of the heat exchangers. Number, length and spacing of ducts taken together allow the storage volume to be calculated. In addition to storage design, due to the low heat transfer rates between circulating fluid and ground, these systems have shown dependence on the development of buffer storage techniques (e.g., water tanks).

Well construction is the predominant part of the costs for aquifer heat storages. In reality, depending on site specific conditions, several serious problems have to be solved, e.g., clogging of wells, scaling of the external heat exchangers, necessity of water treatment, high heat losses especially in small aquifer storage projects like the one in Rostock (Lottner et al. 2000, Schmidt et al. 2004, Bauer et al. 2010).

As some authors suggest, the specific storage costs are related to water equivalent storage volume. The water equivalent is the corresponding water volume to store the same amount of heat. Experiences carried out in demonstrations plants have achieved cost reduction by increasing the storage volume in large-scale solar applications. Figure 3 presents the cost data of some pilot and demonstration plants reviewed in this study, where the two fitting curves indicate the range of investment cost variation. The strong cost reduction with an increasing storage volume is obvious.

The economy of CSHPSS depends not only on the storage costs, but also on the thermal performance of the storage and the connected system. Before starting the design of a new plant, geological conditions of the location, characteristics of the heat source and demands of the consumers have to be analyzed thoroughly. Important parameters are maximum and minimum operating temperatures of the storage and district heating net. Optimal size of solar collector area and storage volume are of vital importance.

The operational characteristics of the different CSHPSS, considered in this paper, are based on simulated values for long term performance of the solar plants. In Bauer et al. (2010), three different seasonal thermal energy storages have been tested and monitored under realistic operating conditions: Friedrichshafen (water tank), Neckarsulm (boreholes), and Rostock (aquifer). Their operational characteristics are compared using measured data from an extensive monitoring program. The long term operational experiences are shown.

The solar fraction based on total heat demand for the plant in Friedrichshafen, for the period 1997-2007, varied between 21 and 33\%, where the design value has been $43 \%$. One of the reasons for not reaching targeted values is because the resulted heat demand of the buildings has been $10 \%$ higher than expected. In addition the design return temperatures of the heat distribution network have been assumed lower than measured values (yearly average weighted by volumetric flow) of $40^{\circ} \mathrm{C}$. Because of the high net return temperatures, the thermal energy storage has been operating at higher than design temperatures, which has resulted in increased heat losses of the thermal storage between $322 \mathrm{MWh} / \mathrm{a}$ and $482 \mathrm{MWh} / \mathrm{a}$, in contrast to design values of $220 \mathrm{MWh} / \mathrm{a}$. The higher operating temperature of the thermal storage has caused also higher temperatures in the solar collector circuit and thus reduced collector efficiency.

The CSHPSS in Neckarsulm has been monitored in the period 1999-2007. The solar fractions achieved (based on total heat demand) have been between 17 and $44.8 \%$, where the design value has been $50 \%$. Reasons for not 
achieving the desired solar fractions have been the $10 \%$ smaller solar colectors' area, than design, and the higher net return temperatures of the heat distribution net $\left(47-50^{\circ} \mathrm{C}\right.$ instead of $\left.40^{\circ} \mathrm{C}\right)$. In addition, the highest achieved solar fraction of $44.8 \%$ has been obtained during the last year of monitoring, when the maximum borehole seasonal storage temperature has reached $65^{\circ} \mathrm{C}, 20^{\circ} \mathrm{C}$ lower than planned. The smaller solar collector area and the heat up of the surrounding ground have contributed to that effect.

Costs of Seasonal Stores (with planning, without VAT)

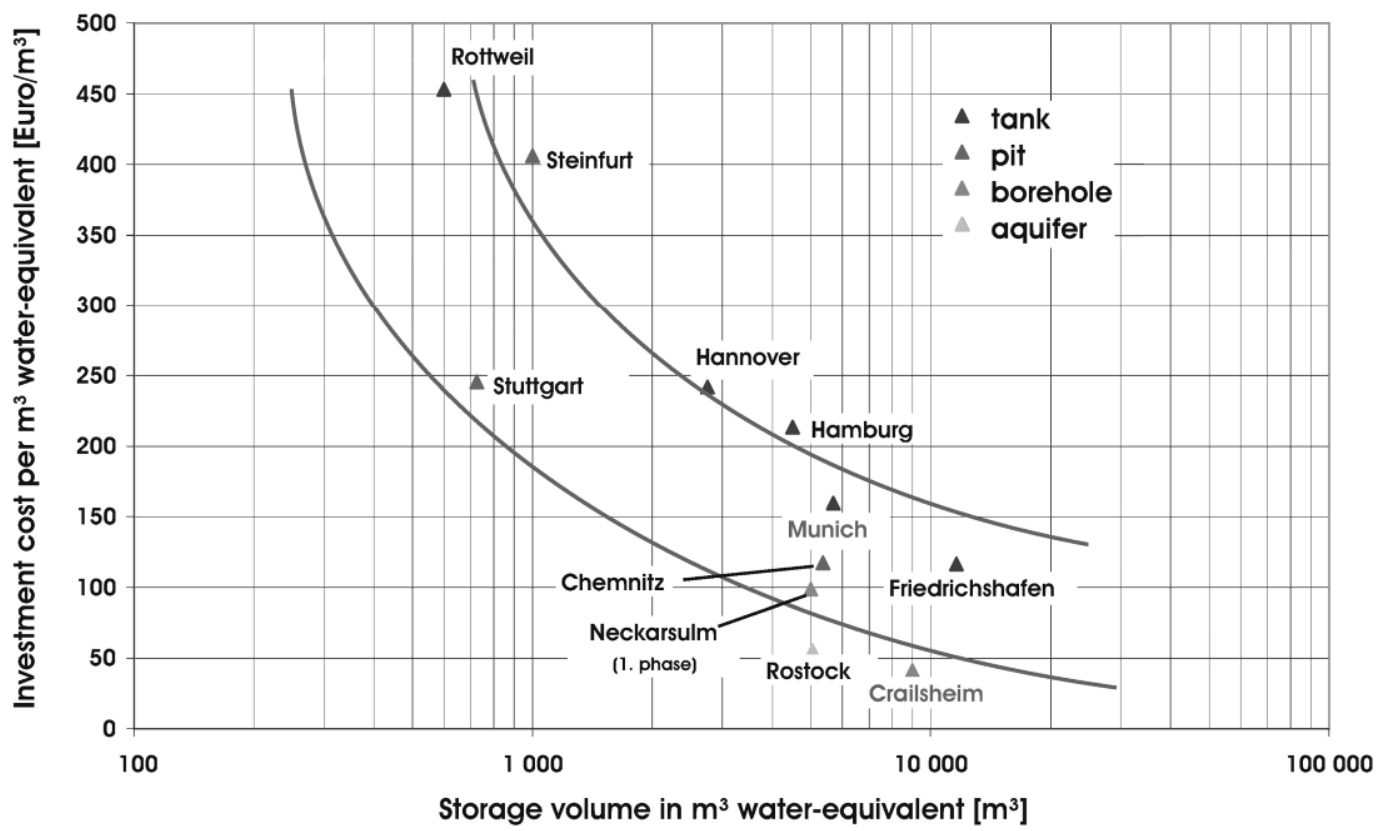

Fig. 3: Cost of seasonal stores for Central Solar Heating Plants with Seasonal Storage (Lottner et al. 2000, Schmidt et al. 2004, Mangold 2007)

Monitoring results from the solar heating plant with aquifer seasonal storage in Rostock have shown solar fractions from 32 to $57 \%$. The maximum temperature of the storage has been limited to $50^{\circ} \mathrm{C}$ due to local hydrogeological conditions. The heat distribution net has been operating at $45 / 30^{\circ} \mathrm{C}$ supply/return temperatures, which required the use of a heat pump for utilization of the stored heat. Due to the use of the heat pump and the high efficiency of the aquifer storage, the system has managed to reach the high solar fraction values.

To summarize, the results from the monitoring campaigns at the different solar plants have shown that, in order to achieve high solar energy efficiency, the solar plants have to be operated at low temperatures. Low storage temperature limits heat losses and improves solar collector efficiencies. Suitable techniques for fully benefitting from such low temperature systems are to use low-temperature heating systems (typical range: $25-35^{\circ} \mathrm{C}$ ) like floor and wall heating in the buildings. In contrast high temperature systems must be built in a much bigger scale than low temperature systems because of the higher storage heat losses.

For seasonal storage, low temperature concepts with the use of heat pumps to raise the temperature of the water used for space heating to a suitable level is an appropriate option. This technology, conceptually and practically implemented in the plants in Rostock, Ehhenstein and Crailsheim (Lottner et al. 2000, Schmidt et al. 2004, Bauer et al. 2010) and in conceptual phase for the plant in Okotoks (Chapuis and Bernier 2009), enables the utilization of the full potential of solar heating plants with seasonal storage. Using a heat pump to discharge the seasonal storage to lower temperatures allows higher usability and increased storage capacity and storage efficiency. The solar plant becomes more robust against high return temperatures of the heat distribution net and solar collectors net, which allows to reduce the solar collector area required, increase the solar collectors' efficiency, and obtain high solar fractions (based on total heating demand).

In the assessment of central solar heating plant up to now in the text has been discussed only the solar fraction as a parameter. In addition, the efficiency of solar assisted district heating systems can be evaluated by the amount of solar heat per $\mathrm{m}^{2}$ collector area delivered into the district heating net. Even though this parameter is dependent on local site conditions, like irradiation on the collector pane, it could give insight into any advantages or disadvantages of using different storage concepts. The monitoring results from the different plants shown in Bauer et al. (2010) do not show any clear tendencies in favor of or against a certain storage concept. 
In addition, the above discussed parameter could give some design prerequisites regarding solar collector area and storage volume. Different methods for determining the optimal size of collector area and storage volume for seasonal storage of solar heat have been developed. Braun et al. (1981) described a methodology for the design of these systems using the simulation program TRNSYS (Klein 2004). Significant reduction in the collector area has been achieved by use of seasonal storage. This effect is more pronounced for higher solar fractions. It has been shown that the trade-offs between collector area and storage volume requirements, for a fixed system performance, are location dependent. Greater reductions in collector area requirements with increasing storage capacity occur in northern latitudes (valid for the northern hemisphere). Simillar results have been confirmed from the demonstration plants studied by Lottner et al. (2000), Schmidt et al. (2004) and Bauer et al. (2010). However, no clear guidelines or design recommendations have been developed.

\section{Conclusions}

Summarizing the findings from computer simulation studies and monitoring campaigns, reviewed in this paper, it is evident that although well developed and also widely used in some countries, the concept of central solar heating plants with seasonal storage of solar energy requires further research activities in order to make it economically competitive with conventional energy sources. Studies related to cost reductions for construction of the storage; heat insulation and reduction of storage heat losses; operating temperatures of the storage, solar collectors net and heat distribution net in regards to efficiently utilizing the low-temperature concept with the use of heat pumps; efficiency of solar collectors; determining of optimal solar collector area and seasonal storage volume; coupling between solar plant and low-temperature heating systems in the buildings; are needed.

\section{References}

Bauer, D., R. Marx, J. Nußbicker-Lux, F. Ochs, W. Heidemann, H. Müller-Steinhagen. 2010. German Central solar heating plants with seasonal heat storage. Solar Energy, 84:612-623.

Braun, J.E., S.A. Klein, J.W. Mitchell. 1981. Seasonal storage of energy in solar heating. Sol En, 26:403-411.

Chapius, S., M. Bernier. 2009. Seasonal storage of solar energy in borehole heat exchangers, In Proc. IBPSA Conf. Building Simulations 2009, Glasgow, Scotland, 599-606.

Claesson, J., Eftring, G. Hellström, Johansson. 1981. Duct storage model. Dept. of Mathematical Physics, University of Lund, Sweden.

Dalenbäck, J.O. 2007, Large scale solar heating and cooling systems in Europe. In Proc. ISES Solar World Congress 2007: Solar Energy and Human Settlement, Vols. I-V:799-803.

Dalenbäck, J.O, T. Jilar. 1985. Swedish solar heating with seasonal storage-design, performance and economy. Int J Amb Energy, 6(3):123-128.

Dincer, I., M. A. Rosen. 2011. Thermal Energy Storage: Systems and Applications. 2nd Ed., John Wiley \& Sons, Ltd., 620 pp.

Energinet.dk. 2007. Solar heat storages in district heating networks. Project no. 2006-2-6750.

Fisch, M. N., M. Guigas, J. O. Dalenbäck. 1998. A review of large-scale solar heating systems in Europe. Sol Energy, 63(6):355-366.

Hahne, E. 2000. The ITW solar heating system: an oldtimer fully in action. Sol Energy, 69(6):469-493.

Heller, A. 2000. 15 years of R\&D in central solar heating in Denmark. Sol Energy, 69(6):437-447.

Hellström, G. 1989. Duct Ground Heat Storage Model: Manual for Computer Code. Dept. of Mathematical Physics, Univ. of Lund, Sweden.

Klein, S. A. 2004. TRNSYS 16 - A TRaNsient SYstem Simulation program. Sol En Lab, University of Wisconsin, USA.

Kübler, R., N. Fisch, E. Hahne. 1997. High temperature water pit storage projects for the seasonal storage of solar energy. Sol Energy, 61(2):97-105. 
Lottner, V., M. E. Schulz, E. Hahne. 2000. Solar-assisted district heating plants: Status of the German programme Solarthermie-2000. Sol Energy, 69(6):449-459.

Lundh, M., J. O. Dalenbäck. 2008. Swedish solar heated residential area with seasonal storage in rock: Initial evaluation. Renewable Energy, 33:703-711.

Mangold, D. 2007. Seasonal storage - a German success story. Sun \& Wind Energy, 1:48-58.

Mazzarella, L. 1989. Duct storage model for TRNSYS 1989 version. ITW, Stuttgart Univ., Dipartimento di Energetica, Politechnico di Milano, Italy.

Mazzarella, L. 1990. The MINSUN Simulation and Optimization Program. User' s Manual, Dipartimento di Energetica, Polytecnico di Milano, Italy.

McDowell, T. P., J. W. Thornton. 2008. Simulation and model calibration of a large-scale solar seasonal storage system. In Proc. 3rd National conference of IBPSAUSA, Berkeley (California), USA.

Nordell, B., G. Hellstrom. 2000. High temperature solar heated seasonal storage system for low temperature heating of buildings. Solar Energy, 69:511-523.

Nordell, B., B. Sanner. 1998. Underground thermal energy storage with heat pumps - An international overview. IEA Heat Pump Centre Newsletter, 16:10-14.

Nordell, B. 2000. Large-scale Thermal Energy Storage. WinterCities’2000, Luleå, Sweden.

Novo, A. V., J. R. Bayon, D. Castro-Fresno, J. Rodriduez-Hernandez. 2010. Review of seasonal heat storage in large basins: Water tanks and gravel-water pits. Applied Energy, 87:390-397.

Nußbicker, J., D. Mangold, W. Heidemann, H. Müller-Steinhagen. 2003. Solar Assisted District Heating System With Duct Heat Store In Neckarsulm-Amorbach (Germany). In Proc. ISES Solar World Congress 2003, Göteborg, Sweden.

Pahud, D. 1996. Duct storage model for TRNSYS 1996 version. LASEN-EPFL, Lausanne, Switzerland.

Pfiel, M., H. Koch. 2000. High performance-low cost seasonal gravel/water storage pit. Sol En, 69(6):461-467.

Schmidt, T, D. Mangold, H. Müller-Steinhagen. 2004. Central solar heating plants with seasonal storage in Germany. Solar Energy, 76:165-174.

Schmidt, T., D. Mangold. 2006. New steps in seasonal thermal storage in Germany. In Proc. Ecostock 2006, Richard Stockton College of New Jersey, USA.

Schmidt, T., F. Kabus, H. Müller-Steinhagen. 2000. The central solar heating plant with aquifer thermal energy store in Rostock, Germany. In Proc. Terrastock 2000, Stuttgart, Germany:275-278.

Schmidt, T., D. Mangold, H. Müller-Steinhagen. 2003. Seasonal Thermal Energy Storage in Germany. In Proc. ISES Solar World Congress 2003, Göteborg, Sweden.

Sibbitt, B., T. Onne, D. McClenahan, J. Thornton, A. Brunger, J. Kokko, B. Wong. 2007. The Drake Landing Solar Community Project - early results. In Proc. 2-nd Canadian Sol. Build. Conf., Calgary, Canada.

Wong, W. P., J. L. McClung, A. L. Snijders, J. P. Kokko, D. McClenahan, J. Thornton. 2006. First large-scale solar seasonal borehole thermal energy storage in Canada. In Proc. Ecostock 2006 Conf, Stockton, NJ USA. 